\title{
Correlations of Leaf Relative Water Content, Canopy Temperature, and Spectral Reflectance in Perennial Ryegrass Under Water Deficit Conditions
}

\author{
Yiwei Jiang ${ }^{2}$ \\ Department of Agronomy, Purdue University, 915 West State Street, West \\ Lafayette, IN 47907-2054
}

Huifen Liu ${ }^{1}$

Department of Agronomy, Tianjian Agricultural University, Tianjin, China 300384

\author{
Van Cline \\ Center for Advanced Turf Technology, The Toro Company, Bloomington, \\ MN 55420-1196
}

Additional index words. turfgrass, Lolium perenne L., drought

\begin{abstract}
Accurate, rapid, and nondestructive estimates of turfgrass leaf water status are important for site-specific irrigation and drought stress management. The objective of this study was to identify changes and correlations among the canopy reflectance, canopy temperature, and leaf relative water content (RWC) of perennial ryegrass (Lolium perenne L.) under water deficit conditions. Six cultivars of perennial ryegrass were subjected to dry-downs in the field from May to Aug. 2007 and from June to Aug. 2008. Turf quality was positively correlated with soil moisture (SM), RWC, and normalized difference vegetation index (NDVI), but negatively correlated with canopy and ambient temperature differentials $(\Delta \mathrm{T}) . \Delta \mathrm{T}$ was well correlated with RWC $(r=-0.77$ to -0.78$)$ and SM $(r=-0.66$ to -0.74$)$, whereas SM was correlated with RWC $(r=0.64$ to 0.74$)$ across seasons in both years. When a wide range of stress symptoms occurred in July and Aug., RWCs became highly correlated with $\Delta \mathrm{T}(r=-0.80$ to -0.89$)$ and NDVI $(r=0.77$ to $0.81)$, whereas $\Delta$ T was correlated with NDVI $(r=-0.70$ to -0.80$)$ in both years. SM was well correlated with RWC $(r=0.71$ to 0.80$)$, NDVI $(r=0.70$ to 0.73$)$, and $\Delta \mathrm{T}(r=-0.76$ to -0.78$)$ in July and August in both years. These results suggest that changes in $\Delta \mathrm{T}$ can be used to predict well the leaf water and soil moisture content of perennial ryegrass under water deficit conditions. Combined with NDVI, the correlations can be used for direct mapping of the variability in grass water status, thus improving irrigation management.
\end{abstract}

The decreasing availability of water has become more of a problem for turf management as a result of regional and localized drought, population growth, and a growing demand for water from competing uses. Improved irrigation management is important for enhancing turf performance during periods of drought stress and for conserving water. Determining plant and soil water content in response to water deficit conditions is beneficial for turfgrass site-specific irrigation management, particularly for locations that show large spatial and temporal

Received for publication 18 Nov. 2008. Accepted for publication 4 Jan. 2009.

This research was supported by the Toro Company. We thank Kehua Wang and Ying Wang for assisting in data collection.

${ }^{1}$ Visiting Scholar.

${ }^{2}$ To whom reprint requests should be addressed; e-mail yjiang@purdue.edu. variability in drought symptoms. Therefore, rapid and accurate assessment of turfgrass water status along with visual observation is essential for timely and proper irrigation as well as for drought stress management in turfgrass.

Leaf and soil water content and chlorophyll concentration are normally affected by water deficit in turfgrass (DaCosta et al., 2004; Jiang and Huang, 2000). These physiological changes can be measured by evaluating leaf or canopy reflectance without destructive sampling because spectral reflectance in the visible and infrared regions is closely associated with leaf pigment content (Bell et al., 2004; Cater and Spiering, 2002; Stiegler et al., 2005) and water content (Penuelas et al., 1993; Rollin and Milton, 1998). Turf quality, color, and leaf firing under water deficit conditions are highly correlated with spectral reflectance at a specific wavelength and/or with various indices derived from two or more wavelengths (Bell et al., 2002; Jiang and Carrow, 2005). The normalized difference vegetative index (NDVI), defined as $\left(\mathrm{R}_{\mathrm{NIR}}-\mathrm{R}_{\mathrm{red}}\right) /\left(\mathrm{R}_{\mathrm{NIR}}+\right.$ $\mathrm{R}_{\text {red }}$ ), is one of the most widely used indices for evaluating turfgrass canopy characteristics (Jiang et al., 2003; Sönmez et al., 2008; Trenholm et al., 1999; Xiong et al., 2007). Once the correlations between canopy reflectance and physiological variables have been identified, relationships among these characteristics can be used to predict turf quality as well as the occurrence of stress and grass tissue water status in different species and cultivars. Furthermore, sensor-based tools may be developed and adapted to provide field mapping of turfgrass stress characteristics. For turfgrass water use, canopy reflectance and related models have been studied to predict soil water content (DettmanKrues et al., 2008) and tissue moisture content (Baghzouz et al., 2006) as well as to evaluate irrigation programs (Hutto et al., 2006; Sönmez et al., 2008; Xiong et al., 2007) in both cool-season and warm-season turfgrass species. In addition to models developed in different turf species, models have been evaluated and optimized to assess drought responses for individual cultivars within a turfgrass species (Jiang and Carrow, 2007).

Responses of turfgrass to water deficit conditions can also be assessed by leaf or canopy temperature. Leaf temperature will be greater than ambient temperature when grasses are under drought stress as a result of reduced transpiration. The plant canopy temperature-ambient air temperature differential could reflect the water balance of a plant and has been studied as a tool in scheduling irrigation in Kentucky bluegrass (Poa pratensis L.) (Throssell et al.,1987). Significant correlations were found between broadbandbased normalized difference vegetation index (NDVI; R600-650; R800-890) and canopy temperature $(r=0.54)$ and between NDVI and tissue moisture content $(r=0.90)$ in drought-stressed tall fescue [Schedonorus phoenix (Scop.) Holub] (Fenstermaker-Shaulis et al., 1997). These results provide information for further studying the relationships between canopy temperature and leaf and soil water content in different turfgrass species and cultivars.

Rapid and accurate estimates of plant and soil water content are critical for maximizing irrigation efficiency in turfgrass management. However, laboratory assessment of leaf relative water content is a time-consuming process, especially when a large number of samples are needed. As a result of the potential variations in drought response of turfgrass in the field, the use of multiple remote sensors to detect changes in canopy temperature and reflectance patterns may allow turfgrass performance under water deficit conditions to be more precisely assessed and spatially characterized. However, to date, the potential use of canopy temperature to predict leaf water content and its correlation with reflectance indices under water deficit conditions is not well understood 
in turfgrass species or cultivars. Although canopy reflectance has been studied as a means to identify relationships between canopy variables and soil moisture conditions, the relationships among spectral reflectance, leaf water content, and canopy temperature have not been studied extensively in turfgrass species. It is not clear if the changes in NDVI reflect the changes in leaf water content. A knowledge of the correlations among leaf relative water content (RWC), NDVI, and canopy temperature could aid irrigation management in improving turf quality. Perennial ryegrass (Lolium perenne L.) is a commonly used turfgrass species on golf course fairways, where spatial variations in drought stress often occur. Therefore, the objective of this study was to identify the changes and correlations among the canopy reflectance, canopy temperature, and RWC of perennial ryegrass under water deficit conditions.

\section{Materials and Methods}

Plant materials. The experiment was conducted at the Turfgrass Research and Diagnostic Center at Purdue University, West Lafayette, IN, from 10 May to 11 Aug. 2007 and from 1 June to 29 Aug. 2008. Six cultivars (BrightStar SLT, Catalina II, Divine, Inspire, Manhattan 4, Silver Dollar) of perennial ryegrass were established from seed in Sept. 2005 on silt loam soil with a $\mathrm{pH}$ of 6.8 . Each cultivar was seeded into four plots (four replications) of $9.3 \mathrm{~m}^{2}(3.05 \mathrm{~m} \times 3.05 \mathrm{~m})$ each. All the grasses were mowed three times a week at $2.54 \mathrm{~cm}$ until drought stress occurred. All the plots received nitrogen $(\mathrm{N})$ at a rate of $48.8 \mathrm{~kg} \cdot \mathrm{ha}^{-1} \mathrm{~N} \approx 10$ May, 15 Sept., and 5 Nov. each year. Irrigation was applied as necessary to maintain healthy turfgrass before the initiation of drought stress through dry-down.

Data collection and analysis. The drydown was initiated after bringing all the grasses to well-watered conditions and then withholding water. Data collection began before the initiation of the drought and continued throughout the dry-down period when there was little or no precipitation. The dry-downs were imposed from 12 to 22 May, 11 to 17 June, 29 July to 11 Aug. 2007 and 1 to 22 June, 20 to 29 July, and 2 to 29 Aug. 2008; and data were collected during these time periods. In 2008, frequent light rain occurred in May causing data collection to be delayed until June. Measurements were not taken if rainfall occurred during these dry-down periods.

Turf quality (TQ) was rated visually based on color, shoot density, and uniformity on a 1 to 9 scale, in which $1=$ dead brown turf and 9 = ideal dark-green color, density, and uniformity for the species. Leaf samples were collected randomly across individual plots for leaf RWC measurements. Leaf RWC was determined according to the following equation: $\mathrm{RWC}=(\mathrm{FW}-\mathrm{DW}) /(\mathrm{SW}-\mathrm{DW}) \times$ $100 \%$, where $\mathrm{FW}$ is leaf fresh weight, DW is the dry weight of leaves after drying at $85^{\circ} \mathrm{C}$ for $3 \mathrm{~d}$, and SW is the turgid weight of leaves after soaking in water for $4 \mathrm{~h}$ at room temperature $\left(\approx 20^{\circ} \mathrm{C}\right)$. A soil moisture probe (TDR 100; Spectrum Tech Inc., Plainfield, IL) was used to determine average volumetric soil moisture content (SM) from 0 to $10 \mathrm{~cm}$ deep.

The duration of each dry-down was determined by how rapidly the TQ and SM declined in response to water deficit conditions. The dry-down created a progression of stress symptoms, which were captured in the turf quality, leaf RWC, canopy temperature, and reflectance measurements. After the end of each dry-down (volumetric SM below $20 \%$ and TQ below 6.0 in the end), grasses were rewatered to a nonstress level before the next dry-down started.

Canopy spectral reflectance was collected with a Crop Circle ACS-210 (Holland Scientific Inc., Lincoln, NE). The machine has a built-in light sensor that incorporates its own patented light source technology, simultaneously emitting visible and near infrared light (NIR) from a single light-emitting diode light source. The area of plant canopy illumination was identical for both visible and infrared light bands, essentially mimicking the spatial composition of natural light. A reflectance at wavelengths 880 and $650 \mathrm{~nm}$ was used to calculate the NDVI (R880 $\mathrm{R} 650) /(\mathrm{R} 880+\mathrm{R} 650)$. The crop circle radiometer was held at a height of $1 \mathrm{~m}$ above the canopy and measured across the entire plot. On each sampling day, a total of 150 to 200 reflectance data points were taken from each plot and the values were averaged. The canopy and air temperature differential $(\Delta \mathrm{T})$ was taken using a handheld infrared thermometer (Everest InterScience Inc., Tucson, AZ) in full sun, and at least two readings for each plot were measured and the means were calculated. The reflectance and canopy temperature readings were taken at 1300 HR along with TQ, RWC, and SM readings.

The experiment was a completely randomized design with four replications for each cultivar. Correlation coefficients $(r)$ were determined using the Statistical Analysis System (9.1 edition; SAS Institute, 1987) to develop relationships among TQ, SM, RWC, $\Delta \mathrm{T}$, and NDVI. The data collected on each sampling day were averaged for a single cultivar across the four replications, and the means were combined for all cultivars across the entire dry-down to run correlation analyses for a particular year.

Table 1. Weather conditions in West Lafayette, IN, during the experiment period from May to Aug. 2007 and 2008.

\begin{tabular}{ccccccc}
\hline Year & Month & $\begin{array}{c}\text { Mean maximum } \\
\text { air temp. } \\
\left({ }^{\circ} \mathrm{C}\right)\end{array}$ & $\begin{array}{c}\text { Mean minimum } \\
\text { air temp. } \\
\left({ }^{\circ} \mathrm{C}\right)\end{array}$ & $\begin{array}{c}\text { Total } \\
\text { precipitation } \\
(\mathrm{mm})\end{array}$ & $\begin{array}{c}\text { Mean solar } \\
\text { radiation } \\
\left(\mathrm{mJ}^{-2} \mathrm{~m}^{-2}\right)\end{array}$ & $\begin{array}{c}\text { Mean wind } \\
\text { speed } \\
\left(\mathrm{ms}^{-1}\right)\end{array}$ \\
\hline 2007 & May & 26.4 & 12.1 & 32.3 & 20.3 & 3.3 \\
& June & 28.1 & 15.7 & 47.0 & 21.3 & 2.6 \\
& July & 27.7 & 15.1 & 55.9 & 23.2 & 2.2 \\
2008 & Aug. & 30.5 & 17.9 & 22.4 & 17.6 & 1.9 \\
& June & 27.8 & 16.9 & 65.3 & 22.7 & 3.1 \\
& July & 28.3 & 16.6 & 68.8 & 23.8 & 2.2 \\
& Aug. & 27.5 & 14.6 & 27.4 & 21.7 & 1.8 \\
\hline
\end{tabular}

Mean maximum air temperatures and mean minimum air temperatures (averaged over 3 months from June to Aug.) were slightly higher in 2007 than they were for the corresponding months in 2008 (Table 1). Total precipitation was higher from June to Aug. 2008 than in 2007. For both years, drought stress was sufficiently high in July and August, which allowed a wide range of drought symptoms to develop in the perennial ryegrass.

There were significant year effects for RWC, NDVI, and $\Delta \mathrm{T}$. No cultivar effects and no year $\times$ cultivar interactions were observed for all measurements, including TQ, SM, RWC, NDVI, and $\Delta \mathrm{T}$. The means of all measurements were presented across all cultivars but separated by years.

Turf quality, soil moisture, and leaf relative water content. The average TQ across six cultivars decreased to an unacceptable level (below 6.0) during the dry-down period in May and from July to Aug. 2007 and in June and July to Aug. 2008 (Tables 2 and 3 ). The average SM across cultivars decreased from $34.9 \%$ to $17.7 \%$ in May and from $37.1 \%$ to $15.2 \%$ from July to Aug. 2007 (Table 2), whereas SM decreased from $36.0 \%$ to $21.0 \%$ in June and from $30.3 \%$ to $12.1 \%$ from July to Aug. 2008 (Table 3). RWC across cultivars decreased from $94.5 \%$ to $88.0 \%$ in May and from $94.3 \%$ to $71.5 \%$ from July to Aug. 2007 (Table 2) and decreased from $93.4 \%$ to $89.2 \%$ in June and from $93.3 \%$ to $68.1 \%$ from July to Aug. 2008 (Table 3). The July to August dry-down in both years caused further reductions in TQ, $\mathrm{SM}$, and RWC compared with the dry-downs in May 2007 or June 2008. From the beginning to the end of drought stress, the TQ of perennial ryegrass declined gradually, which allowed the relationship between TQ and canopy reflectance to be examined, similar to another study using different turfgrass species grown in containers (Jiang and Carrow, 2007). In this study, the decreasing TQ, SM, and RWC from July to August resulted in significant changes in canopy temperature and reflectance in both years.

Normalized difference vegetation index and temperature differential. No significant changes in NDVI were observed in May 2007 or June 2008, although TQ, SM, and RWC all decreased (Tables 2 and 3 ). It seems that NDVI was not much affected when drought 
Table 2. Turf quality (TQ), soil moisture (SM), leaf relative water content (RWC), normalized difference vegetative index (NDVI), and canopy and air temperature differential $(\Delta \mathrm{T})$ averaged across all cultivars before and after drought in 2007.

\begin{tabular}{|c|c|c|c|c|c|c|c|c|c|c|c|c|}
\hline \multirow[b]{2}{*}{$\begin{array}{l}\text { Treatment/ } \\
\text { measurement }\end{array}$} & \multicolumn{6}{|c|}{ May } & \multicolumn{6}{|c|}{ July to August } \\
\hline & TQ & $\begin{array}{l}\text { SM } \\
(\%)\end{array}$ & $\begin{array}{c}\text { RWC } \\
(\%)\end{array}$ & NDVI & $\begin{array}{l}\Delta \mathrm{T} \\
\left({ }^{\circ} \mathrm{C}\right)\end{array}$ & $\begin{array}{l}\text { Stress duration }(\mathrm{d}) / \\
\text { sampling events }\end{array}$ & TQ & $\begin{array}{l}\text { SM } \\
(\%)\end{array}$ & $\begin{array}{c}\text { RWC } \\
(\%)\end{array}$ & NDVI & $\begin{array}{l}\Delta \mathrm{T} \\
\left({ }^{\circ} \mathrm{C}\right)\end{array}$ & $\begin{array}{c}\text { Stress duration }(\mathrm{d}) \\
\text { sampling events }\end{array}$ \\
\hline Before stress & $6.7 \mathrm{a}^{\mathrm{z}}$ & $34.9 \mathrm{a}$ & $94.5 \mathrm{a}$ & $0.77 \mathrm{a}$ & $-2.4 \mathrm{~b}$ & & $7.3 \mathrm{a}$ & $37.1 \mathrm{a}$ & $94.3 \mathrm{a}$ & $0.72 \mathrm{a}$ & $-1.9 \mathrm{~b}$ & \\
\hline After stress & $4.9 \mathrm{~b}$ & $17.7 \mathrm{~b}$ & $88.0 \mathrm{~b}$ & $0.74 \mathrm{a}$ & $4.6 \mathrm{a}$ & $14 / 9$ & $3.0 \mathrm{~b}$ & $15.2 \mathrm{~b}$ & $71.5 \mathrm{~b}$ & $0.65 \mathrm{~b}$ & $7.4 \mathrm{a}$ & $13 / 8$ \\
\hline
\end{tabular}

${ }^{\mathrm{z}}$ Means followed by the same letters within a column for a given measurement were not significantly different at $P<0.05$.

Table 3. Turf quality (TQ), soil moisture (SM), leaf relative water content (RWC), normalized difference vegetative index (NDVI), and canopy and air temperature differential $(\Delta \mathrm{T})$ averaged across all cultivars before and after drought stress in 2008.

\begin{tabular}{|c|c|c|c|c|c|c|c|c|c|c|c|c|}
\hline \multirow[b]{2}{*}{$\begin{array}{l}\text { Treatment/ } \\
\text { measurement }\end{array}$} & \multicolumn{6}{|c|}{ June } & \multicolumn{6}{|c|}{ July to August ${ }^{2}$} \\
\hline & TQ & $\begin{array}{l}\text { SM } \\
(\%)\end{array}$ & $\begin{array}{c}\text { RWC } \\
(\%)\end{array}$ & NDVI & $\begin{array}{c}\Delta \mathrm{T} \\
\left({ }^{\circ} \mathrm{C}\right)\end{array}$ & $\begin{array}{c}\text { Stress duration }(\mathrm{d}) / \\
\text { sampling events }\end{array}$ & TQ & $\begin{array}{l}\text { SM } \\
(\%)\end{array}$ & $\begin{array}{c}\text { RWC } \\
(\%)\end{array}$ & NDVI & $\begin{array}{l}\Delta \mathrm{T} \\
\left({ }^{\circ} \mathrm{C}\right)\end{array}$ & $\begin{array}{c}\text { Stress duration }(\mathrm{d}) \\
\text { sampling events }\end{array}$ \\
\hline Before stress & $6.8 \mathrm{a}^{2}$ & $36.0 \mathrm{a}$ & $93.4 \mathrm{a}$ & $0.76 \mathrm{a}$ & $-2.2 \mathrm{~b}$ & & $6.8 \mathrm{a}$ & $30.3 \mathrm{a}$ & $93.3 \mathrm{a}$ & $0.81 \mathrm{a}$ & $-0.5 b$ & \\
\hline
\end{tabular}

${ }^{2}$ Means followed by the same letters within a column for a given measurement were not significantly different at $P<0.05$.

stress began to occur. However, in July and August, NDVI dropped $9.7 \%$ and $17.3 \%$ in 2007 and 2008, respectively. The decreases in RWC in July and August caused leaf wilting, which in turn resulted in considerable reductions in NDVI. NDVI is highly correlated with TQ and leaf firing under a range of drought stress (Jiang and Carrow, 2005; Sönmez et al., 2008). Unlike NDVI, $\Delta \mathrm{T}$ significantly increased with decreasing TQ, SM, and RWC in May 2007 or June 2008. When grasses are healthy and turgid, canopy temperature is lower than air temperature. The significant increase in $\Delta \mathrm{T}$ indicated that grasses were drought-stressed, causing a reduction in transpiration during the dry-down periods in both years (Tables 2 and 3).

Correlations among turf quality, soil moisture, leaf relative water content, normalized difference vegetation index, and temperature differential. Significant correlations among all variables were observed from May to Aug. 2007 and from June to Aug. 2008 (Tables 4 and 5). Those correlations were stronger from July to August in both years, particularly for NDVI with SM, RWC,

Table 4. Correlations among turf quality (TQ), soil moisture (SM), leaf relative water content (RWC), normalized difference vegetative index (NDVI), and canopy and air temperature differential $(\Delta \mathrm{T})$ across all cultivars and all trials in both 2007 and 2008.

\begin{tabular}{|c|c|c|c|c|c|c|c|c|}
\hline \multirow[b]{2}{*}{ Correlations } & \multicolumn{4}{|c|}{$2007(\mathrm{~N}=126)$} & \multicolumn{4}{|c|}{$2008(\mathrm{~N}=96)$} \\
\hline & SM & RWC & NDVI & $\Delta \mathrm{T}$ & SM & RWC & NDVI & $\Delta \mathrm{T}$ \\
\hline TQ & $0.80^{* * *}$ & $0.78^{* * *}$ & $0.74 * * *$ & $-0.84 * * *$ & $0.61 * * *$ & $0.73 * * *$ & $0.77 * * *$ & $-0.74 * * *$ \\
\hline SM & & $0.64 * * *$ & $0.30^{* * *}$ & $-0.74 * * *$ & & $0.74 * * *$ & $0.22 * * *$ & $-0.66^{* * *}$ \\
\hline RWC & & & $0.72 * * *$ & $-0.78 * * *$ & & & $0.39 * *$ & $-0.77 * * *$ \\
\hline NDVI & & & & $-0.67 * * *$ & & & & $-0.50 * * *$ \\
\hline
\end{tabular}

Table 5. Correlations among turf quality (TQ), soil moisture (SM), leaf relative water content (RWC), normalized difference vegetative index (NDVI), and canopy and air temperature differential $(\Delta \mathrm{T})$ across all cultivars from July to August trial in both 2007 and 2008.

\begin{tabular}{|c|c|c|c|c|c|c|c|c|}
\hline \multirow[b]{2}{*}{ Correlations } & \multicolumn{4}{|c|}{$2007(\mathrm{~N}=48)$} & \multicolumn{4}{|c|}{$2008(\mathrm{~N}=48)$} \\
\hline & SM & RWC & NDVI & $\Delta \mathrm{T}$ & SM & RWC & NDVI & $\Delta \mathrm{T}$ \\
\hline$\overline{\mathrm{TQ}}$ & $0.91 * * *$ & $0.79 * * *$ & $0.72 * *$ & $-0.90 * * *$ & $0.73^{* * *}$ & $0.76^{* * *}$ & $0.94 * * *$ & $-0.76^{* * *}$ \\
\hline SM & & $0.71 * * *$ & $0.70^{* * *}$ & $-0.76 * * *$ & & $0.80^{* * *}$ & $0.73 * * *$ & $-0.78^{* * *}$ \\
\hline RWC & & & $0.81^{* * *}$ & $-0.89^{* * *}$ & & & $0.77 * *$ & $-0.80^{* * *}$ \\
\hline NDVI & & & & $-0.80 * * *$ & & & & $-0.70^{* * *}$ \\
\hline
\end{tabular}

**,***Significant at 0.01 and $0.001 P$ level, respectively. and $\Delta \mathrm{T}$ in 2008 (Table 5). There was relatively more rainfall from June to July in 2008 in 2007, which could have reduced the stress response of the turf and therefore affected the relationships among water status, canopy temperature, and reflectance. The correlaa wides variables improved when July and August of both years.

TQ was positively correlated with SM, RWC, and NDVI but negatively correlated ith $\Delta \mathrm{T}$ (Tables 4 and 5 ). $\Delta \mathrm{T}$ was wel correlated with RWC ( $r=-0.76$ to -0.78$)$ and SM $(r=-0.66$ to -0.74$)$, whereas SM was seasons was well correlated with NDVI $(r=0.70$ to $0.76)$ and $\Delta \mathrm{T}(r=-0.76$ to -0.78$)$, whereas RWC was highly correlated with NDVI ( $r=$ both 0.81$)$ and $\Delta \mathrm{T}(r=-0.80$ to -0.89$)$ in correlated with $\Delta \mathrm{T}(r=-0.70$ to -0.80$)$ Dettman-Krues et al. (2008) found that volumetric soil water content was best predicted with creeping bentgrass (Agrostis stolonifera L.) canopy reflectance data

. reflectance response of annual ryegrass to changes in nitrogen application and leaching fractions. Intl. J. Remote Sens. 27:4137-4157.

Bell, G.E., B.M. Howell, G.V. Johnson, W.R. Raun, J.B. Solie, and M.L. Stone. 2004. Optical sensing of turfgrass chlorophyll content and tissue nitrogen. HortScience 39:1130-1132.

Bell, G.E., D.L. Martin, S.G. Wiese, D.D. Dobson, M.W. Smith, M.L. Stone, and J.B. Solie. 2002. Vehicle-mounted optical sensing: An objective means for evaluating turf quality. Crop Sci. 42:197-201.

Carter, G.A. and B.A. Spiering. 2002. Optical properties of intact leaves for estimating chlorophyll concentration. J. Environ. Qual. 31:1424 1432.

DaCosta, M., Z. Wang, and B. Huang. 2004. Physiological adaptation of Kentucky bluegrass to localized soil drying. Crop Sci. 44: 1307-1314.

Dettman-Krues, J.K., N.E. Christians, and M.H. Chaplin. 2008. Predicting soil water content through remote sensing of vegetative characteristics in a turfgrass system. Crop Sci. 48:763-770. 
Fenstermaker-Shaulis, L.K., A. Leskys, and D.A. Devitt. 1997. Utilization of remotely sensed data to map and evaluate turfgrass stress associated with drought. J. Turfgrass Mgt. 2:65-80.

Hutto, K.C., R.L. King, J.D. Byrd, and D.R. Shaw. 2006. Implementation of hyperspectral radiometry in irrigation management of creeping bentgrass putting greens. Crop Sci. 46:1564-1569.

Jiang, Y. and R.N. Carrow. 2005. Assessment of narrow-band canopy spectral reflectance and turfgrass performance under drought stress. HortScience 40:242-243.

Jiang, Y. and R.N. Carrow. 2007. Broadband spectral reflectance models of turfgrass species and cultivars to drought stress. Crop Sci. 47: 1611-1618.

Jiang, Y., R.N. Carrow, and R.R. Duncan. 2003. Correlation analysis procedures for canopy spectral reflectance data of seashore paspalum under traffic stress. J. Amer. Soc. Hort. Sci. 128:343-348.

Jiang, Y. and B. Huang. 2000. Effects of drought or heat stress alone and in combination on Kentucky bluegrass. Crop Sci. 40:1358-1362.

Penuelas, J., I. Filella, C. Biel, L. Serrano, and R. Save. 1993. The reflectance at the $950-970 \mathrm{~nm}$ region as an indicator of plant water status. Intl. J. Remote Sens. 14:1887-1905.

Rollin, E.M. and E.J. Milton. 1998. Processing of high spectral resolution reflectance data for the retrieval of canopy water content information. Remote Sens. Environ. 65:86-92.

SAS Institute. 1987. SAS user's guide: Statistics. 9.1 Ed. SAS Inst., Cary, NC.

Sönmez, N.K., Y. Emekli, M. Sari, and R. Bastug. 2008. Relationships between spectral reflectance and water stress conditions of bermuda- grass (Cynodon dactylon L.). New Zealand J. Agr. Res. 51:223-263.

Stiegler, J.C., G.E. Bell, N.O. Maness, and M.W. Smith. 2005. Spectral detection of pigment concentrations in creeping bentgrass golf. Intl. Turfgrass Soc. Res. J. 10:818-825.

Throssell, C.S., R.N. Carrow, and G.A. Milliken. 1987. Canopy temperature based irrigation scheduling indices for Kentucky bluegrass turf. Crop Sci. 27:126-131.

Trenholm, L.E., R.N. Carrow, and R.R. Duncan. 1999. Relationship of multispectral radiometry data qualitative data in turfgrass research. Crop Sci. 39:763-769.

Xiong, X., G.E. Bell, J.B. Solie, M.W. Smith, and B. Martin. 2007. Bermudagrass seasonal responses to nitrogen fertilization and irrigation detected using optical sensing. Crop Sci. 47: $1603-1610$. 